\title{
Improving Students' TOEFL Score by Applying Discourse Strategies on TOEFL Listening Part A in Program Intensif Bahasa Asing (PIBA) of Universitas Islam Negeri (UIN) Alauddin, Makassar
}

\author{
Muhammad Syihab As'ad \\ muh.syihab.asad@gmail.com
}

Universitas Islam Negeri Alauddin, Makassar, Indonesia

\begin{abstract}
This research was aimed to give an encouraging sight of students about reaching a good score on TOEFL. Then, this research facilitated the students to find the best way of increasing their TOEFL listening score in part A which is the focus of this research conducted in PIBA (Program IntensifikasiBahasaAsing) UIN Alauddin, Makassar. This research applied pre-experimental design. The data were collected from the subject which consist of 23 students. In the pre-test, there were only $22 \%$ who reach the good classification. After the treatment, the subjects' score rose significantly by reaching $89 \%$ for good category. It was proven by the data of the mean score in pre-test was 392.61 while post-test got 445.65 for the mean score. The data indicated that the treatment gave slight increase in the research.Moreover, test of significant testing showed that the value of the t-table was higher than t-test.Through the interview, the researcher found that among all students, there were 54\% used the sound-alike word, 38\% applied the restatement idea, and only $8 \%$ used the most different option. Furthermore, this research revealed that the answer of TOEFL listening part A could be determined through intonation. The real situation of a conversation and speaker's intention can be identified by the speaker's intonation. Consequently, the findings and conclusions noted that the technique and strategies applied and revealed in this research were positively proposed. It is concluded that the students' TOEFL score can slightly be increased by using discourse technique and by applying the strategies given in this research.
\end{abstract}

Keywords: TOEFL score, discourse strategies, TOEFL listening part A, intonation.

\section{INTRODUCTION}

Several years ago, TOEFL, Test of English as a Foreign Language, was only considered for English students in non-native countries. Nowadays, it becomes more famous among the people in various fields. In most universities, including Indonesia, TOEFL becomes very important for those who plan to continue their study for graduate and post graduate program in any departments. It cannot be denied that the TOEFL requirement for continuing study is quite difficult for several people. More than $50 \%$ of graduate students in magister program need to take TOEFL course provided by the university after they enrolled in the university. This proves that there are a large number of graduate students who are not ready to face TOEFL. 
This research focuses on listening TOEFL part A which contains diverse types of question which needs more comprehension. The researcher will attach a simple example of listening part A:

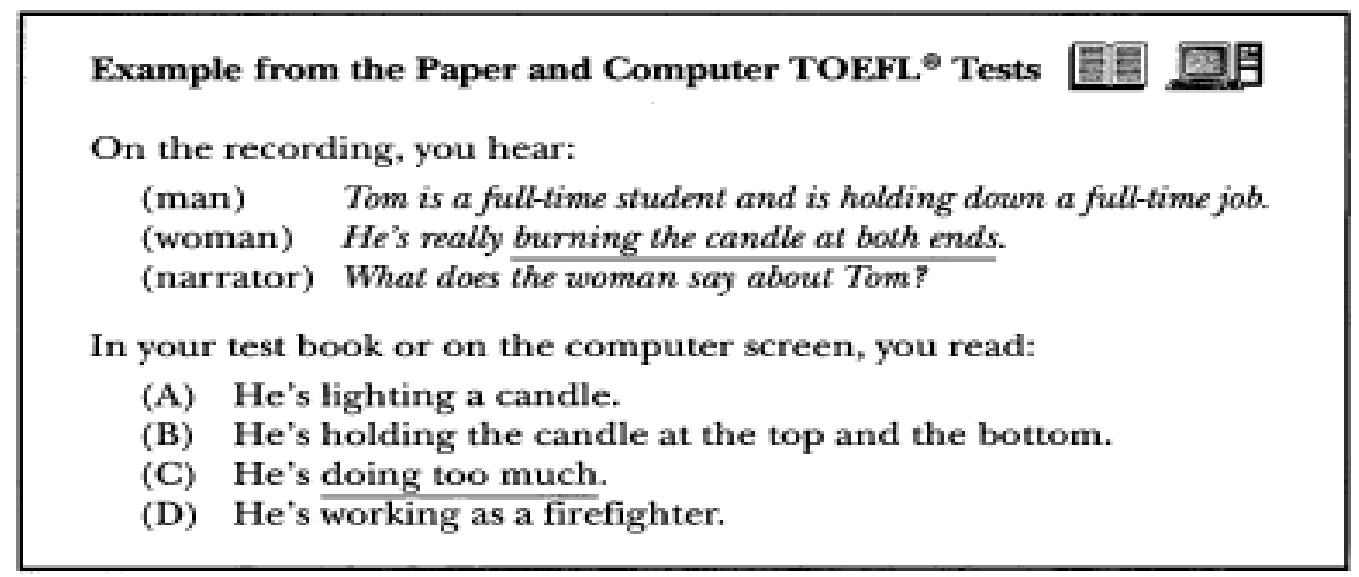

Picture 1.1 The Example of Listening Part A

This question contains an idiom "burning the candle at both ends" which will give confusion to the testee to choose the correct answer. The idiom has nothing to do with fire and candle at all. This expression is used when someone is trying to do more than he/ she really can do. After all, a candle only burns at one end. Therefore, the candle that burns at two ends is doing too much. For that reason, the correct answer is C. Philips (2000: 72).

\section{Review of Related Literature}

Listening and its relation to discourse are generally found both in academic and nonacademic ways. Hale \& Courtney (1994) conducted a study which examined the effect of taking notes in the portion of the TOEFL listening comprehension section that contain monologues, or mini-talks. Sadighi collaborated with Zare (2006) carry a research out in title "Is Listening Comprehension Influenced by the Background Knowledge of the Learners?". They conducted the research in case of increasing focus on L2 listening ability in language learning and acquisition. And the last related research attached is from Jensen \& Hansen (1995) who documented a research about the effect of prior knowledge on EAP listening-test performance. According to those researches, the discourse phenomenon is one of important spots in listening part A. There are many experiments; such as taking-notes, background knowledge, prior knowledge on lectures; conducted to increase the students' comprehension in listening. However, they do not give significant contribution on mini-talks understanding. It is highlighted that to understand the meaning in minitalks, the testee should understand the all records in textual and contextual view. Furthermore, the short conversation part in TOEFL is designed to asses test takers' understanding on a real conversation in a short period of time. Therefore, the previous researches are good but they are not entirely matched in all circumstances, including in answering listening TOEFL part.

\section{Concept of discourse analysis and conversational analysis}

1. Definition of discourse analysis 
Riggenbach (1999) called discourse analysis as 'bigger picture' of language description that is often left out of more micro-level descriptions of language use. It derives people to understand the language use from social and cultural points.

In discourse analysis, especially in this research, there will be three main focuses to interpret the messages in mini-talk TOEFL. Brown and Yule (1984) stated that someone has to be able to make some interpretations through locality and analogy principles. Locality principle gives a point to listener or reader to not create a wider understanding to get the real intent from addressor. Analogical principle can interpret the message by recalling the other event which is almost equivalent or the event that has already been around the addressee. There are three major parts of discourse analysis that will be identified in this study. They are coherence, cohesion, and context.

a) Coherence

According to Agar \& Hobbs (1982: 1) stated that coherence can be further divided into global and local. Local coherence refers to the interrelatedness, or topic maintenance, across adjacent utterances. Global coherence refers to the interrelatedness, or topic maintenance, across larger stretches of discourse (e.g., an entire conversation or narrative). The researcher tries to define the coherence as the neatly setting about the reality, facts, and ideas which is gathered into a logical message then becomes understandable utterances.

b) Cohesion

Rankema (2004: 112) argues that the most salient phenomenon of discourse is the fact that sentence or utterance is linked together. For this "connectedness", this "texture': two concepts are used: cohesion, referring to the connections which have their manifestation in the discourse itself, and coherence. Referring to the connections which can be made by the reader or listener based on knowledge outside the discourse.The aptitude of interrelation among the discourse elements refers to forms and language aspects which consist of sentences. This is what the researcher is trying to sum up about cohesion.

c) Context

Linguists previously analyzed sentences, without concerning the context. The meaning of a sentence can only be recognized as understandable when the speakers, the audience, the pronunciation, and others are identified. For that reason, it is necessary to analyze the sentences contextually before come into the deep interpreting. According to Brown \& Yule (1984) the context is the environment or circumstances where the language is used.

\section{Strategies of answering the listening part A questions}

Philips (2000: 47) argues that even if the test takers do not understand the complete conversation in part $\mathrm{A}$, there is still a possibility to get a correct answer by following some methods. They are the restatement idea, the most different option, and the soundalike word.

These methods will be the second focus of this study. The researcher will analyze how the students of ABA UMI realize these methods. Therefore, there will be a complete listening part A test then followed by interview to discover the methods applied by the students.

1. Restatement Idea

Often, the correct answer in part A is the answer with the synonym words. The test- taker should realize that the keywords from the narrator have the same meaning in the four 
following options. Therefore, it can be stated that what the speaker said in the recorder is not always the answer in the option. The restatement of the talk is always needed to discover the correct answer in mini-talk. Understanding contextually is one of the ways of reaching this points.

Gear (2011: 68)assumes that the tester can guess the meaning of a statement by thinking about the context of a conversation. This absolutely can help the participant to answer correctly. In the TOEFL listening, it is necessary to be more focus on the meaning of all related question than notice the exactly mentioned words that the speaker said. Therefore, the test-taker should fully understand the deep structure occurred in the conversation. Then, the students may answer the mini-talk question based on their understanding of the conversation through contextual comprehension.

\section{The Sound-alike Word}

Some of the items in part A involve confusion between words that have similar sounds. One of the speakers uses a word or phrase that sounds like a word or phrase in one or more of the answer choices. If the test-takers don't hear the word clearly, it might be answered incorrectly when choosing an option with a sound-like word or phrase.

Rodgers (2001: 29) investigates the part A of TOEFL listening. Many sound-alike expressions in part A are minimal pairs which are two words that are pronounced alike except for one vowel sound peel, pill and point, paint or one consonant sound vine, wine and mop, mob. Another sound problem involve one word that sounds like one word, such as mark and marker the last type of sound problem involves in one word that sounds like a part of a longer words. Such as nation and imagination, mind and remind, give and forgive. By observing this method, it can be concluded that the option containing the sound-alike word should be avoided as the correct answer.

\section{The Most Different Option}

From the two previous methods explained, it is concluded that the correct answer is the synonym of the statement and the similar sound should be avoided. This methods explains that often in part $\mathrm{A}$, the most different option should be considerably chosen as the correct answer. The following is the example of this method.

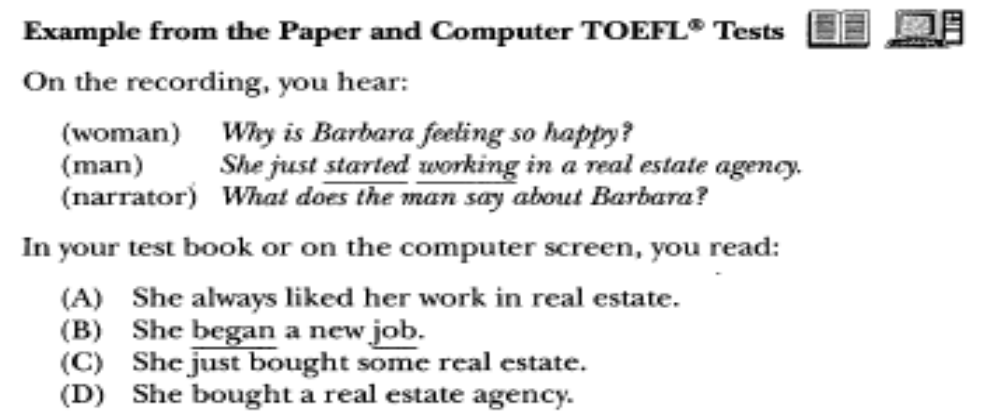

Picture 2.1 The Example of Listening Part A

The keywords from the speaker are underlined then should be noticed as the clues to answer the question. Also, the speaker said real estate words. The test-taker should avoid the words that have been mentioned in mini-talk in order to identify the correct answer. 
The option A, C, and D contain the same words, real estate. Therefore, the answer should be option $\mathrm{B}$ which is the most different option of the others.

\section{Aimed of the study}

This study explores about discourse strategies and students' strategies in answering TOEFL listening part A in PIBA UIN Alauddin Makassar. The objectives of the study are: (a) to find out the effectiveness of discourse strategies in answering TOELF listening part A interaction pattern in PIBA UIN, (b) to find out the kinds of strategies used in PIBA students of UIN.

\section{Methodology}

This study is guided by was pre-experimental design which have pre-test and post-test design. . The comparison between the pre-test and post-test score depend on the how the researcher conduct the treatment to be success. The subjects of the study are the students at PIBA UIN Alauddin Makassar. This class consists of 26 students, yet only 23 student are included into quantitative research from the first research question. In this qualitative research question, the researcher conduct purposive sampling which ends up with 13 students who give better responses. This study uses pre experiment and discourse analysis to process the data. Recording and interview are the instruments that used to observe the strategies used by the students in PIAB UIN. Technique of data analysis is conducted in answering the study questions. It is the form of study finding. In this study, there are three kinds of data provided. Namely; the data from pre and post-test, the data from recording and the data from interview.

\section{Data analysis and results}

Table of the result of students' pre-test and post-test in Experimental Class (See Appendix III) present the experimental group's score in the Pre-test and Post-test. It indicated that the lowest score in the Pre-test was three -hundred and twenty and the highest one was four-hundred and sixty. The student with the lowest score only answered eight questions correctly and forty-two questions incorrectly. The highest scoring students had twenty-two correct answers and twenty-eight incorrect answers.

After the treatment, the students' score increased significantly. The lowest score in the Post-test was three-hundred and eighty. The student with the lowest score answered thirteen questions correctly and thirty-seven questions incorrectly. The highest score in the post-test was four-hundred and ninety. The students with the highest score had twenty-eight correct and twenty-two incorrect answers. It means the lowest score in the Post-test was higher than the lowest one in the Pre-test, and the highest score in the Posttest was higher than the score in the Pre-test.

For the total score, the table demonstrated a significant increase on the students' result after the treatment using discourse technique. The total score in the Pre-test was 9.060, which was much lower than the total score in the Post-test reaching the score of 11.080. It indicated the benefit of using discourse technique in increasing TOEFL score.

Despite the significant increase of the post-test, there were several students who significant increase in the post test. Student no. 12 got 8 correct number in pre-test and increasingly got 22 correct number in post-test. The researcher assumed that he understood well the patterns given and apply it in right way. Despitefully, there were two 
students who did not attend pre-test and there was another who can't attend the post-test. Therefore, they were not included into the data calculation.

In the pre-test none of the students was classified into excellent category for their TOEFL score. There were only five students or $(22 \%)$ of the sample was classified into good, and eighteen students $(78 \%)$ were classified into average, and no students was included into poor. The data are shown in table 1 below;

Table 4.1 The Criteria and Percentage of the Students' Scores in pre-test

\begin{tabular}{llcc}
\hline No Classification & Rate of the score & $\begin{array}{c}\text { Number } \\
\text { of Students }\end{array}$ & $\begin{array}{c}\text { Percentage } \\
(\%)\end{array}$ \\
\hline
\end{tabular}

\begin{tabular}{lllll}
\hline 1. & Excellent & $640-680$ & 0 & 0 \\
\hline 2. & Very good & $540-630$ & 0 & 0 \\
\hline 3. & Good & $440-530$ & 5 & 22 \\
\hline 4. & Average & $340-430$ & 18 & 78 \\
\hline $\mathbf{5 .}$ & Poor & $240-330$ & 0 & 0 \\
\hline & & & 23 & 100 \\
\hline
\end{tabular}

According to the data taken in pre-test, the students' scores were among the average (78\%) category with 18 students, the dominant criteria. The second place was taken by the third category, good criteria. There were $22 \%$ of student who had been placed in this category. Therefore, the student's mastery about verb in TOEFL was in normally.

After the treatment in the post-test, the criteria and percentage were changed. There were 19 students who were classified into good criteria with $83 \%$, four students or $(17 \%)$ of the sample was classified into average, and none student was included into the lowest classification. It indicated that there was a significant increase after the treatment. The data are shown in table 2 below;

Table 4.2 The Criteria and Percentage of the Students' Scores in Post-test

\begin{tabular}{llccc}
\hline No & Classification & $\begin{array}{c}\text { Rate of the } \\
\text { score }\end{array}$ & $\begin{array}{c}\text { Number of } \\
\text { Students }\end{array}$ & $\begin{array}{c}\text { Percentage } \\
(\%)\end{array}$ \\
\hline $\mathbf{1}$ & Excellent & $640-680$ & 0 & 0 \\
\hline $\mathbf{2}$ & Very good & $540-630$ & 0 & 0 \\
\hline $\mathbf{3}$ & Good & $440-530$ & 19 & 83 \\
\hline $\mathbf{4}$ & Average & $340-430$ & 4 & 17 \\
\hline $\mathbf{5}$ & Poor & $240-330$ & 0 & 0 \\
\hline \multicolumn{2}{l}{ Total } & & 23 & 100 \\
\hline
\end{tabular}

To sum up the collected data, the researcher concluded that the highest classification was not reached by students. Hence, it was the highest score in TOEFL test. From both test, it can be resumed that the students who got good classification were increased. The data in 
pre-test was $22 \%$ meanwhile in post-test it was $83 \%$. In the same line with the good classification, the lowest classification also got better results. In pre-test, there were 18 students who got the second lowest classification with $78 \%$. After treatment, it decreased significantly, there were only 4 students who are still in the average classification with $17 \%$. It proved that this technique was useful to gain their TOEFL mastery, especially in section 1.

After classifying students' performance into some labels, the following figure presented the mean score and standard deviation of the experimental class.

Table 4.3 The Mean Score and Standard Deviation of the Experimental Class in the Pre and Post-test

\begin{tabular}{lcclc}
\hline & Mean & N & $\begin{array}{l}\text { Std. } \\
\text { Deviation }\end{array}$ & Std. Error Mean \\
\hline PRETEST & 392.61 & 23 & 43.716 & 9.115 \\
\hline POST-TEST & 445.65 & 23 & 29.822 & 6.218 \\
\hline
\end{tabular}

The table indicated the mean score of experimental class in the Pre-test was 392.61 with the standard deviation 43.716. The mean score of the experimental class in the Post-test was 445.65 and the standard deviation was 29.822 . The post-test was increased as planned.

In the experimental class, the mean score of the post-test was higher than the mean score of the Pre-test. The standard deviation was much closer to zero. Thus, it could be concluded that the use of Discourse Technique is beneficial to improve students' mastery in on section 1 of TOEFL test.

The significant score in this study can be calculated by using t-test. The result of the t-test can be seen in table 4.4 as follows:

Table 4.4 The t-test of Students' Achievement

\begin{tabular}{ccc}
\hline Variable & t-test & t-table \\
\hline $\mathbf{X}_{1}-\mathbf{Y}_{\mathbf{1}}$ & -6.501 & -2.074
\end{tabular}

Table 4.4 shows the result of test of significance testing. For the level of significance $(p)$ 0,05 and the degree of freedom $(\mathrm{df})(\mathrm{N}-1)=(23-1)=22$, showed that the value of the $\mathrm{t}-$ table was higher than t-test. The result of the test clearly showed that there was a significant difference between the students' score in the experimental class after the treatment, discourse technique. It indicated that the discourse technique was effective in improving students' listening comprehension to answer section 1 of TOEFL test. It means $\mathrm{H} 0$ was rejected and $\mathrm{H} 1$ was accepted because the t-test was higher than t-table (-6.501> 2.074). Hence, the researcher's hypothesis was accepted.

This study also found that there are three basic strategy, which is related to theory provided, used by the students in answering TOEFL listing part A. Often, the correct answer in part A is the answer with the synonym words. The test- taker should realize that 
the keywords from the narrator have the same meaning in the four following options. Gear (2011: 68)assumes that the tester can guess the meaning of a statement by thinking about the context of a conversation. This absolutely can help the participant to answer correctly. Therefore, it can be stated that what the speaker said in the recorder is not always the answer in the option. The following paragraphs present the extract of student who use restatement idea as the method. Rodgers (2001: 29) investigates the part A of TOEFL listening and revealed that sound problem involve one word that sounds like one word, such as mark and marker the last type of sound problem involves in one word that sounds like a part of a longer words. Such as nation and imagination, mind and remind, give and forgive. By observing this method, it can be concluded that the option containing the sound-alike word should be avoided as the correct answer. However, there were several students who use the sound-alike word to be the answer. From the two previous methods explained, it is concluded that the correct answer is the synonym of the statement and the similar sound should be avoided. This methods explains that often in part A, the most different option should be considerably chosen as the correct answer. The succeeding part is the extracts of interview about student who commonly use this technique.

Based on the facts of the interview in the data record above, the researcher summarized into diagrams circle below.

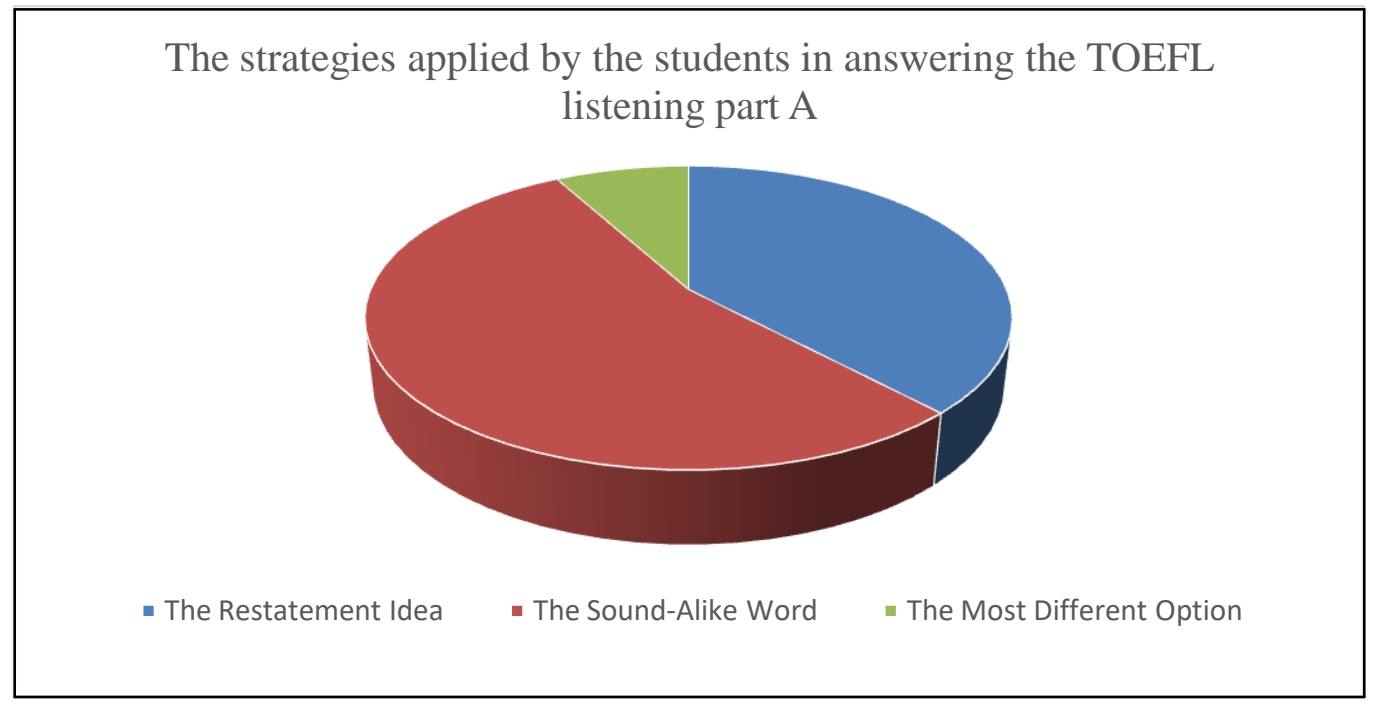

Diagram 4.1 The Strategies Applied by the Students in Answering the TOEFL listening part A

From table of recording recapitulation above, it reveals that most of the student choose an answer in TOEFL listening part A through The Sound-Alike word. They tend to decide the best answer based on the similar sound that they just heard from the speaker. This phenomenon took 54\% above the two others. While the second place is addressed to the Restatement Idea with $38 \%$. There were several students who answer the question through the similar meaning. And this is the best way of finding the correct answer of listening TOEFL part A. The lowest portion of this research is the Most Different Option. This strategy which only took $8 \%$ of the total percentage is an infrequent method among 
the students in finding the correct answer. In the real test, the student sometimes miss the point of a conversation. Therefore, they will get confuse to decide the answer. The last strategy, the most different option, help the students who do not understand the topic of mini-talk by overlooking the options and eliminate the similar option in form. There is still possibility for the student to get the correct answer through this strategy.

Despite the three strategies offered by Philips (2000: 47); The Restatement Idea, The Sound-Alike Word, and The most Different Option, the researcher found a new strategy in answering TOEFL listening part A. Participant no. 10 reveals that he could find the correct answer through intonation.

\section{DISCUSSION}

From the previous explanation, the researcher wish that both problem statements in this research can clearly be answered. The first research question is about the effectiveness of the application of Discourse Strategy in answering the TOEFL listening part A in PIBA UIN. It has been verified by the data provided in this chapter that the level of significance (p) 0,05 and the degree of freedom $(\mathrm{df})(\mathrm{N}-1)=(23-1)=22$, showed that the value of the t-test was higher than t-table. The result of the test clearly showed that there was a significant difference between the students' score in the experimental class after the treatment, discourse technique. It indicated that the discourse technique was effective in improving students' listening comprehension to answer section 1 of TOEFL test. It means H0 was rejected and H1 was accepted because the t-test was higher than t-table (-6.501> 2.074). Hence, the researcher's hypothesis was accepted. It means that the first research question was effective proven by data found.

The second research question focused on the strategy applied by the PIBA students in answering the listening TOEFL part A. This research reveals that the theories exposed by Philips (2000: 47) were applied by the subjects of this research. The findings reveal that most of the student choose an answer in TOEFL listening part A through The SoundAlike word. They tend to decide the best answer based on the similar sound that they just heard from the speaker. This phenomenon took 54\% above the two others. While the second place is addressed to the Restatement Idea with 38\%. There were several students who answer the question through the similar meaning. And this is the best way of finding the correct answer of listening TOEFL part A. The lowest portion of this research is the Most Different Option. This strategy which only took $8 \%$ of the total percentage is an infrequent method among the students in finding the correct answer. By overlooking the options and eliminate the similar option in form, there is still possibility for the student to get the correct answer through this strategy.

Furthermore, the researcher found a new strategy in answering the TOEFL question in part A. This research exposed the new tactic in answering TOEFL listening question through paying attention on the intonation of the speakers. Occasionally, the real situation performed by the speaker in listening TOEFL part A could be determined by the intonation. It has been proved in the last extract in findings.

Therefore, in this study, the researcher conclude that the intonation can reveal the speaker's intention and help the test-taker to answer the question appropriately. From this discussion, the researcher expects that this findings could give a huge contribution for teaching and learning process and directly could be very useful for educational sector. 
To sum up this section, the researcher suggests the test-taker to find the answer through the restatement idea first. Because it is so rational to choose answer based on the similar meaning. The sound-alike words is considered as good strategy if the test-taker understand the appropriate use of this method. The test-taker may focus on the similar sound in case of avoiding the options which contain the homophone word on what speaker said and what listed in the options. In a very last minute, if the test-taker could not reveal the best answer, he/ she is suggested to choose the best answer through the most different option. Occasionally, the best answer is the most different one from other options. This has been proved in this research. In spite of these three basic strategies offered by Philips (2000: 47), the researcher unintentionally found a newest strategy of answering the answer in listening TOEFL part A. It is the intonation of the speaker which can lead the test-taker to find the answer. By focusing the speakers' intonation, the testtaker may set up the real situation in the conversation. Surprisingly, one of the participant realizes this phenomena and take the researcher to a decision that the best answer of listening TOEFL part A could be discovered through intonation or the tone of the speakers.

\section{REFERENCES}

Agar, M., \& Hobbs, J. R. 1982. Interpreting discourse: Coherence and the analysis of ethnographicinterviews. Discourse Processes, 5, 1-32

Boyle, P. J. 1984. Factors Affecting Listening Comprehension. Accessed on $23^{\text {rd }}$ September 2015. Retrieved from http://education.seattlepi.com/factors-affectlistening-comprehension-3720.html

Brown, G.,\& Yule, G. 1984. Discourse Analysis. London: Cambridge University Press.

Creswell, J. W. 2009. Research Design Quantitative and Qualitative, and Mixed Methods Approach, 3rd Edition. USA: Sage Publications.

Creswell, J. W. 2012. Educational Research: Planning, Conducting, and evaluating Quantitative and Qualitative Research, $4^{\text {th }}$ Edition. USA: Pearson.

Dawson, C. 2009. Introduction to Research Methods: A Practical Guide for Anyone Undertaking a Research Project. UK: HowToBooks.

Gear, J. 2011. Cambridge Preparation for the TOEFL Test. Cambridge: Cambridge University Press.

Hale, A. G., \& Courtney, R. 1994.The Effect of Note-Taking on Listening Comprehention in the Test of English as a Foreign Language, (online), Accessed on $23^{\text {rd }}$ September, 2016. Retrieved from 2016. https://sites.google.com/site/themetalibrary/library-genesis.

Halliday, M. A .K.,\&Ruqaiya, H. 1994. BahasaKonteksdanTeks: AspekaspekBahasadalamPandanganSemiotikSosial. (TerjemahanAsruddinBaroriTou). Yogyakarta: UGM Press. (Bukuaslitahunterbit 1985).

Halliday, M. A. K., \&Hasan, R. 1976 .Cohesion in English. London: Longman. [6. 1, 6.2]

Heldner, M. 2008. Pauses, gaps, and overlaps in Conversations. Accessed on $26^{\text {th }}$ January 2016. Retrieved from http://booksc.org/.

Jensen, C., \& Hansen, C. 1995. The Effect of Prior Knowledge on EAP Listening-Test Performance.Accessed on $23^{\text {rd }}$ September 2015. Retrieved from https://sites.google.com/site/themetalibrary/library-genesis.

King, C., \& Nancy, S. 1989. Building Skill for the TOEFL Second Edition. Hong Kong: Nelson Press. 
Liddicoat, A. J. 2007. An Introduction to Conversation Analysis. London: British Library Cataloguing-in-Publication Data.

Lind, C. 2006. Conversation Repair and Adult Cochlear Implantationn: a Qualitative Case Study. Accessed on $26^{\text {th }}$ January 2016. Retrieved from http://booksc.org/.

Louwerse, M. M., \&Graesser, A. C. 2005. Coherence in discourse. In P. Strazny (Ed.), Encyclopedia oflinguistics (pp. 216-218). Chicago, IL: Fitzroy Dearborn.

Mulyana. 2005. Kajianwacana. Yogyakarta: Tiara Wacana

Nunan, D. 1998. Approaches to teaching listening in language classroom.In proceedings of the 1997 Korea TESOL Conference. Taejon, Korea: KOTESOL.

Paltridge, B. 2006. Discourse Analysis an Introduction. London: Continuum. Oxforddictionary. 2016. Definition of Listening. Retrieved on $23^{\text {rd }}$ September, 2015.Fromhttp://www.oxforddictionaries.com/search/?direct=1\&multi=1\&dictC ode=english\&q=listening

Philips, D. 2000. Longman Preparation Course for the TOEFL Test Skill and Strategies. Jakarta: Prenhalindo.

Renkema, J. 2004.Introduction to Discourse Studies.Amsterdam: John Benjamin Publishing.

Riggenbach, H. 1999.Discourse Analysis in the Language Classroom. Volume 1: The Spoken Language. Ann Arbor: The University Michigan Press

Rodgers, B. 2001. TOEFL CBT Success. USA: Thomson Corporation.

Sacks, H.,Schegloff,E.A.,\& Jefferson, G. 1974.A simplest systematic for the organization of turn-taking for conversation. Language, 50, 696-735.

Sadighi, F., \&Zare, S. (2006). Is Listening Comprehension Influenced by the Background Knowledge of the Learners? A Case Study of Iranian EFL learners. Accessed on $23^{\text {rd }} \quad$ September $2015 . \quad$ Retrieved from https://sites.google.com/site/themetalibrary/library-genesis.

Saricoban, A. 1999. The Teaching of Listening.Accessed on $23^{\text {rd }}$ September 2015. Retrieved from http://iteslj.org/Articles/Saricoban-Listening.html

Verbiest, A. 1989. Confrontation in Conversations: The Adjacency Pair as a Tool of the Descriptive Component of a Pragma-dialectical Analysis. Accessed on $26^{\text {th }}$ January 2016. Retrieved from http://booksc.org/.

VOICE Project. 2007. VOICE Transcription Conventions [2.1]. Accessed on 30 February 2014. Retrieved from http:voice.univie.ac.at.

Wiemann, J. M., \& Knapp, M. L. 1975. Turn-taking in Conversations. Accessed on $26^{\text {th }}$ January 2016. Retrieved from http://booksc.org/. 